\title{
EFFECT OF DIETARY MANNAN OLIGOSACCHARIDE AND LIGNIN ON POPULATION AND CHARACTERISTICS OF PROBIOTIC BACTERIA ISOLATED FROM JAPANES QUAILS
}

\author{
Mai M.G. Ahmady ${ }^{1}$, Nahed A. El-Wafai ${ }^{2}$, Mohamed I. Hegazy ${ }^{2}$ and Sahar M.S. Ouda ${ }^{1}$ \\ 1. Plant Res. Dept. Nuclear Res. Cent., Atomic Ener. Authority, Egypt \\ 2. Agric. Microbiol. Dept., Fac. Agric., Zagazig Univ., Egypt
}

Received: 5/4/2017 ; Accepted: 11/04/2017

\begin{abstract}
The role of gut bacteria in animal health has became increasingly important, especially, with limitations use of antibiotics in animal feed due to consumer pressure and legislation. This study showed the relationships between gut bacteria and bird performance as a result of affecting by dietary supplementation of prebiotic such as (mannan oligosaccharide and lignin). A lower count of total aerobic bacteria was shown in mannan and lignin groups comparing with control during all experimental periods. Fortunately, count of the probiotic bacteria (Bifidobacterium spp. and Lactobacillus spp.) increased significantly $(\mathrm{P} \leq 0.01)$ in lignin and mannan groups compared to the control group at all three periods age, while the most increases were at 9 weeks. Determination of the susceptibility of isolated probiotics to antibiotics exhibited that the most effective antibiotic against the tested bacteria was ciprofloxacin (CIP), which reached up to $32 \mathrm{~mm}$ of inhibition zone, followed by vancomycin (VA) reaching up to $22 \mathrm{~mm}$ and finally tetracyclin (TE) which reached up to $20 \mathrm{~mm}$. The antibacterial activity of the crude supernatant fluids obtained from lactic acid bacteria (LAB) culutures was generally greater against the Gram positive than the Gram negative tested bacteria. Sequencing of the 16S rRNA gene technique was considered to be a rapid and powerful method for identifying the probiotic isolates of Bifidobacterium spp. and Lactobacillus spp. to the species and at sub species level as Bifidobacterium longum subsp. infantis, Bifidobacterium animalis subsp. lactis and Lactobacillus acidophilus.
\end{abstract}

Key words: Bifidobacterium spp., antibiotics, antimicrobial, probiotic, prebiotic, Japanese quail.

\section{INTRODUCTION}

Gut microbiology and its role in animal health has become increasingly important, particularly now, that the use of antibiotics in animal feeds to promote growth is facing restrictions due to legislation in some countries and consumer pressure. The microorganisms that colonise the gastrointestinal tract during the early post-hatch period form a synergistic relationship with their poultry host. Gastrointestinal microorganisms have a highly significant impacts on uptake and utilization of energy (Choct et al., 1996) and other nutrients (Steenfeldt et al., 1995; Smits et al., 1997) and

\footnotetext{
*Corresponding author: Tel. :+201111607690

E-mail address: bonyahmady@yahoo.com
}

on the response of poultry to anti-nutritional factors (such as non-starch polysaccharides), pre- and probiotic feed additives and feed enzymes (Apajalahti and Bedford, 2001). Microorganisms can also directly interact with the lining of the gastrointestinal tract (Van Leeuwen et al., 2004), which may alter the physiology of the tract and immunological status of the bird (Klasing et al., 1999).

Antibiotic substances have been added to livestock animal feeds as growth promoters since 1950, (Gibson and Roberfroid, 1995) because it was found that their use improved the performance and health of the animals. Nevertheless, in recent years, the public 
disapproval for antibiotic growth promoters, due to their residual effects, has created a growing interest in the identification and evaluation of alternative natural feed additives (Greko, 2001; Roe and Pillai, 2003). One such additive that is being tested as growth promoter is the mannan oligosaccharides (MOS) of the cell wall of the yeast Saccharomyces cerevisiae. When MOS are incorporated in the animal feed, they can adhere to pathogenic bacteria that have type-I fimbriae, and so, limit their ability to adhere to the mucosa of the digestive tract and multiply.

Prebiotics are non-digestible but fermentable food ingredients that beneficially affect the host by selectively stimulating the growth and activity of one or number of bacteria in the colon (Gibson and Roberfroid, 1995). The beneficial effects of prebiotics are known, and they are widely used as an alternative to antibiotics in poultry (Rehman et al., 2009), also they increase the number of bifidobacteria and lactobacilli, whereas the number of Salmonella spp. and E.coli in the gastrointestinal tract are reduced (Nelson et al., 1994). Alcell lignin (1.25\% of DM) has been reported to improve growth performance of veal calves and to inhibit the growth of Escherichia coli in vitro (Phillip et al., 2000).

The objectives of this study were to determine the effects of dietary addition of lignin and a mannan oligosaccharide to Japanes quails diets on probiotic populations in the cecum and determination the susceptibility of Bifidobacterium as well as Lactobacillus bacteria isolated from the cecum of Japanes quail to several groups of antibiotics, Also, Bifidobacterium spp. and Lactobacillus spp. were screened of their antagonistic activity against some pathogenic bacteria.

\section{MATERIALS AND METHODS}

\section{Bird Management and Experimental Design}

Part of the present study was carried out at the laboratory belonging to the Poultry Physiology and Production Research Unit, Biological Applications Department, Nuclear Research Center, Atomic Energy Authority, Egypt. Ninety 1-day-old Japanes quail, were individually weighed and assigned randomly to 3 treatment groups with 30 birds each. The birds were housed in separate wire suspended cages until 64 days of age. All experimental birds were housed in galvanized metal cages equipped with an automatic nipple drinker and manual feeder. The birds were grown in these cages $(100 \times 60 \times$ $50 \mathrm{~cm}$; length $\times$ width $\times$ height), with ad libitum access to water and feed, at the same managerial, controlled, clean and hygienic environmental conditions. The composition and calculated chemical analyses of the basal diet are presented in Table 1.

The basal diet was given to control (group 1), while second group was fed diet with the addition of $1.25 \%$ lignin (L)/Kg diet (group 2). The Alcell lignin used was (Alcell Technologies Inc., Montreal, Quebec, Canada), and third group was fed basel diets supplemented with $0.2 \% \mathrm{~g}$ mannan oligosaccharide $/ \mathrm{kg}$ diet (group 3 ). The MOS used was "MOS 500" (Ultra BioLogics Inc., Canada). The experimental basal diet was formulated to meet the recommendations of NRC (1994). The quails were allowed add libitum access to feed and water.

Vaccination against the Newcastle disease (ND) virus was performed on days 21,42 and 64 of age separately, using an eye dropper (Live Lasota strain; KBNP, Inc.; Hungnam, Korea). Artificial light source was used in order to give 24 hours of light per day throughout the experimental period.

\section{Bacteriological Analyses}

\section{Bacterial populations of cecal digesta}

Cecal contents of each bird were aseptically emptied into sterile plastic bag at 21, 42 and 64 day of age, and stored at $-20^{\circ} \mathrm{C}$ for bacteriological analyses. Samples of the cecal contents were serially diluted in $0.85 \%$ sterile saline solution and used to assay lactobacilli, bifidobacteria, E. coli and total aerobic bacteria. All bacteriological analyses were performed in 3 replicates, and the average value of these determinations were used for statistical analysis. Lactobacilli were anaerobically assayed using lactobacilli MRS agar (Fisher Scientific, Ottawa, Ontario, Canada) by serial dilution $\left(10^{-5}-10^{-7}\right)$ and incubated at $37^{\circ} \mathrm{C}$ for $48 \mathrm{hr}$., (Baurhoo et al., 2007b). Enumeration of bifidobacteria was performed using Wilkins-Chalgren agar (Oxoid, Nepean, Ontario, Canada) by serial dilution $\left(10^{-5}\right.$ $\left.10^{-7}\right)$. The Petri dishes were placed in anaerobic 
Table 1. Ingredients and calculated chemical composition of the basal diet

\begin{tabular}{lc}
\hline Ingredient & $\mathbf{( \% )}$ \\
\hline Yellow corn & 60.50 \\
Soybean meal (44\%) & 26.00 \\
Maize gluten meal (62\%) & 8.00 \\
Vegetable oil & 1.50 \\
Limestone & 1.12 \\
Di-calcium phosphate & 1.75 \\
Premix* & 0.30 \\
NaCl (salt) & 0.30 \\
L-lysine & 0.36 \\
DL-Methionine & 0.17 \\
Total & 100 \\
Calculated composition** & \\
ME (kcal kg ${ }^{-1}$ ) & 3050.00 \\
Crude protein & 22.06 \\
Calcium & 0.95 \\
Non phytate phosphorus & 0.45 \\
Lysine & 1.3 \\
TSAA & 0.95 \\
Threonine & 0.78 \\
Tryptophan & 0.22 \\
\hline
\end{tabular}

*Provides each Kg of diet: Vitam. A: $12000 \mathrm{IU}$, Vitam. $\mathrm{D}_{3}: 5000 \mathrm{IU}$, Vitam. E: $130.0 \mathrm{mg}$, Vitam $\mathrm{K}_{3}: 3.605 \mathrm{mg}$, Vitam. $B_{1}: 3.0 \mathrm{mg}$, Vitam. $\mathrm{B}_{2}: 8.0 \mathrm{mg}$, Vitam. $\mathrm{B}_{6}: 4.95 \mathrm{mg}$, Vitam. $\mathrm{B}_{12}: 0.17 \mathrm{mg}$, Niacin: $60.0 \mathrm{mg}$, Folic acid: $2.083 \mathrm{mg}$, D-Biotin: $200.0 \mathrm{mg}$, calcium D-Pantothenate: $18.333 \mathrm{mg}$, Copper: $80 \mathrm{mg}$, Iodine: $2.0 \mathrm{mg}$, Selenium: $150.0 \mathrm{mg}$, Iron: $80.0 \mathrm{mg}$, Manganese: $100.0 \mathrm{mg}$, Zinc: $80.0 \mathrm{mg}$, Cobalt $500.0 \mathrm{mg}$.

** Calculated according to NRC (1994).

jars, using anaeropacks (Oxoid), and incubated at $37^{\circ} \mathrm{C}$ for 5 days (Baurhoo et al., 2007b). Escherichia coli was assayed using Mac-Conkey agar -Difco, by serial dilution $\left(10^{-3}-10^{-4}\right)$ and incubated aerobically at $37^{\circ}$ for $24 \mathrm{hr}$ (Baurhoo et al., 2007b). Total aerobic bacterial count was estimated on plate count agar (medium-Difco, using decimal dilution technique. Plates were incubated at $37^{\circ} \mathrm{C}$ for $48 \mathrm{hr}$., after which colony forming units (CFU) were counted by serial dilution $\left(10^{-5}-10^{-7}\right)$. Average results of the replicates are presented as $\log _{10}$ colony forming units $(\mathrm{CFU}) / \mathrm{g}$ of the cecal content (Swanson et al., 2001).

\section{Isolation of probiotic bacteria}

During the enumeration of bifidobacteria and lactobacilli colonies in their specific media in Petri-dishes as recommended by (Baurhoo et al., 2007 b), the isolation process was conducted during the time course of the experimental period at different stages of age and treatments to isolate probiotic bacteria from the highest dilutions $\left(10^{-6}-10^{-7}\right)$ prepared from the cecal 
contents. In each case, single colonies were picked up, grown, purified, chcked by microscopic examination, subculutred and preserved as recommended methods due to Swanson et al. (2001). Totality 27 lactobacilli isolates and 26 bifidobacteria isolates were obtained, and due to the growth characterization, only 6 isolates were selected for further study.

\section{Antibiotic susceptibility test}

The antibiotic susceptibility test was performed by the standard disc diffusion method (NCCLS, 2004). The following commercial antiobiotic discs were used: Gentamicin (CN $10 \mathrm{mcg}$ ), Neomycin (N $30 \mathrm{mcg}$ ), Amoxicillin (AX 25 mcg), Streptomycin (S $10 \mathrm{mcg}$ ), Erythromycin (E $15 \mathrm{mcg}$ ), Penicillin (G $10 \mathrm{mcg}$ ), Cefotaxime (CTX $30 \mathrm{mcg}$ ), Chloramphenicol (C 30 $\mathrm{mcg}$ ), Vancomycin (VA $30 \mathrm{mcg}$ ), Aminosidin (AN 60 $\mathrm{mcg}$ ), Trimethoprim/Sulphamethoxazole (SXT $1.25 \mathrm{mcg}$ ), Tetracycline (TE $30 \mathrm{mcg}$ ), Kanamycin (K $30 \mathrm{mcg}$ ), Ciprofloxacin (CIP 5 $\mathrm{mcg}$ ) and Ampicillin (AM $10 \mathrm{mcg}$ ). Pure cultures of Bifidobacterium and Lactobacilllus were enriched in LB broth at $37^{\circ} \mathrm{C}$ for $24 \mathrm{hr}$. Using a strile glass spreader, $100 \mu 1\left(2 \times 10^{8}\right.$ CFU/ ml) from each bacterial culture were spread onto LB agar plates (Costa et al., 1998). The antibiotic discs were dispensed sufficiently separated from each other, so as to avoid overlapping of inhibition zones. After $30 \mathrm{~min}$, the plates were inverted and incubated at $37^{\circ} \mathrm{C}$ for 18-24 hr. Results were recorded by measuring the diameter of the inhibition zones (mm) and compared with standards for antimicrobial disk susceptibility tests.

\section{Antibacterial activity of the isolated Lactobacillus and Bifidobacterium}

The isolated lactobacilli and bifidobacterium were grown in MRS broth at $37^{\circ} \mathrm{C}$, for 2 days for lactobacilli, and for 4-5 days for Bifidobacterium were placed in anaerobic jars, using anaeropacks (Oxoid). Cultures were centrifuged at $12000 \mathrm{~g}$ for $10 \mathrm{~min}$ at $4^{\circ} \mathrm{C}$, and the supernatant fluids were adjusted to $\mathrm{pH} 6.5$ with $1 \mathrm{~N} \mathrm{NaOH}$, and filtered through a $0.45 \mu \mathrm{m}$ membrane filter for obtaining the cell-free supernatants (CFSs). After the preparation of CFS of all lactobacilli and Bifidobacterium strains, antibacterial activity was determined by a disk diffusion assay (Herreros et al., 2005).
Ten milliliters of Brain heart infusion agar $(1.5 \% \mathrm{~W} / \mathrm{V})$ was poured into a sterile plate and solidified. Brain heart infusion agar $(0.7 \%, W / V)$ was first seeded with an indicator bacterial strain $(36 \mu l$ of overnight culture per $6 \mathrm{ml}$ of agar, i.e. approximately $10^{7}$ cells). Nine indicator bacterial strains namely (Listeria monocytogenese, Salmonella enteric, E.coli 0157 : H7, Enterobacter cloacae subsp. dissolvens, Enterobacter aerogenes, Micrococcus caseolyticus, Aeromounas hedrophili, Staphylococcus aureus and Staphylococcus H.) were kindly provided by the Dept. Agric. Microbiology Fac. Agric. Zagazig Univ., Egypt were used in this study. The inoculated soft agar was rapidly dispensed onto an agar plate. After solidification, the soft agar was dried for $30 \mathrm{~min}$. under a laminar flow hood. Aliquot of $50 \mu \mathrm{l}$ from each extract of CFSs were placed on the disk. Plates were held at room temperature for 3 hr., to allow the antibacterial agent to diffuse completely, and were incubated for $24 \mathrm{hr}$., at $37^{\circ} \mathrm{C}$. Antibacterial activity was expressed as the diameter of zone of inhibition (including the disc) which was recorded by measuring the diameter of the inhibition zones $(\mathrm{mm})$.

\section{Biochmical and molecular identification of bacterial isolates}

Only, six bifidobacteria and lactobacilli bacteria isolated from cecum of japanes quailes were identified using biochemical methods according to Martin-Carnahan and Joseph (2005). The isolated bacteria in pure culture were grown on Luria Bertani (LB) agar plates and subjected to catalase test, oxidases, urease test, hydrogen sulfide production test, indole test, methyl red, citrate utilization, motility and Voges-Proskaür test. Also, pure bacterial isolates were grown in peptone water supplemented with $0.5 \%$ of the tested sugar i.e., glucose, mannitol, sucrose, sorbitol, trehalose, raffinose, ribose, cellobiose, lactose, mannose, inositol and rhamnose after being sterilized by filtiration. Bromothymol blue and small inverted Durham's tube were included in each tube. Acid production and gas production were detected according to Samelis et al. (1994). To confirm the biochemical results, only three isolates were identified in Sigma Scientific Services Company (El-Giza, Egypt) using 16S rDNA gene sequence. The DNA of the bacteria was isolated according to the protocol of Maniatis et al. 
(1989), and the GeneJet genomic DNA purification Kit (Thermo K0721). Molecular sequencing of the DNA fragment containing the $16 \mathrm{~S}$ intergenic spacer corresponding to the conserved region of 16S rDNA (MartinezMurcia et al., 1992) allowed for an unambiguous classification of the Bifidobacterium and Lactobacillus isolates. The primers designs to amplify $16 \mathrm{~S}$ rDNA gene were: forward primer 5AGAGTTTGATCATGG CTCAG-3 and reverse primer 5'-GGTTACCTT GTTACGACTT-3' and the identification was performed according to Borrell et al. (1997).

\section{Statistical Analysis}

Data were analyzed as an one-way ANOVA using the GLM procedure. Treatment means were separated using Bonferroni's multiple comparison test. Statistical significance was declared at a probability of both $P \leq 0.05$ and $P$ $\leq 0.01$. All bacteriological values were subject to base-10 logarithm transformation before analysis due to (Snedecor and Cochran, 1982).

\section{RESULTS AND DISCUSSION}

\section{Bacterial Loads in Cecum of Japanes Quail}

Results presented in Table 2 show bacterial count of cecum of Japanes quail birds as affected by dietary supplementation of mannan oligosaccharide and lignin. The count of total aerobic bacteria was insignificantly affected in group 2 (lignin) and group 3 (mannan) compared to the control group during the experiments duration. A lower count of total aerobic bacteria was shown in mannan and lignin groups comparing with control group during all experimental periods. The effect of prebiotics supplementation on the native probiotics showed that, the count of Bifidobacterium spp. significantly increased ( $\mathrm{P}$ $\leq 0.01$ ) in lignin and mannan groups compared to the control group at all three periods of age. Moreover, mannan was more potent for increasing Bifidobacterium compared to lignin group at all the tested bird age.

Counts of Lactobacillus spp. significantly increased $(\mathrm{P} \leq 0.05)$ in lignin and mannan groups during all expermintal periods compared to the control group. Also, the values were significantly increased $(\mathrm{P} \leq 0.05)$ in lignin group compared to mannan group at 3,6 and 9 weeks of age. But, the results showed that total aerobic bacteria and E. coli were decreased with the advancing of age, whereas, count of Lactobacillus spp. and Bifidobacterium spp. increased with the advancing of age.

A similar trend was observed, as the count of E.coli non-significantly decreased in lignin and mannan groups during all the experimental periods compared to the control group. Supplementation induced a significant reduction in $E$. coli count than the antibiotic supplemented and control group. While, the antimicrobial growth parameter-supplemented group induced a significant reduction in the total aerobic count than the prebiotic and control groups.

On the other hand, pathogenic microbiota decreased in response to prebiotic supplementation. Escherichia coli was reported to decrease in response to prebiotic mannan oligosaccharidesupplementation (Gouveia et al., 2006; Swanson and Fahey, 2006; Middelbos et al., 2007). Also, other studies reported a reduction in E.coli count with mannan oligosaccharide supplementation (Xu et al., 2003; Zdunczyk et al., 2005; Baurhoo et al., 2007a,b).

Lignin and Mannan oligosaccharides have been found to have beneficial effects on broiler. They have been shown to stimulate beneficial bacteria while also having a negative effect on pathogenic bacteria, e.g. Escherichia coli and Salmonella spp. in the broiler gut (Spring et al., 2000; Baurhoo et al., 2007a). However, the results of Yang et al. (2008) reported decrease in ilial and cecal lactobacilli with mannan oligosaccharide supplementation. Langlands et al. (2004) found that the prebiotics oligosaccharides changed bacterial species numbers in both the proximal and distal gut, significantly increasing bifidobacteria, lactobacilli, while decreasing clostridia in the distal gut (Langlands et al., 2004). A large number of authors observed changes in microbiota reported increased bifidobacteria (Swanson and Fahey, 2006 and Middelbos et al., 2007). The reason for this might be that prebiotic could increase the population of 
Table 2. Changes in bacterial counts $(\log \mathrm{cfu} / \mathrm{ml})$ in cecum of Japanes quail as affected by dietary supplementation of mannan-oligosaccharides and lignin

\begin{tabular}{|c|c|c|c|c|c|}
\hline Treated birds & $\begin{array}{c}\text { Age } \\
\text { (week) }\end{array}$ & $\begin{array}{c}\text { T. aerobic } \\
\text { bacteria }\end{array}$ & E. coli & $\begin{array}{c}\text { Bifidobacterium } \\
\text { Spp. }\end{array}$ & $\begin{array}{c}\text { Lactobacillus } \\
\text { Spp. }\end{array}$ \\
\hline Group 1 (control) & \multirow{3}{*}{$\frac{\pi}{8}$} & $6.60 \pm 0.07$ & $5.49^{\mathrm{a}} \pm 0.42$ & $7.39^{c} \pm 0.07$ & $5.92^{\mathrm{c}} \pm 0.24$ \\
\hline Group 2 (lignin) & & $6.38 \pm 0.06$ & $4.42^{\mathrm{ab}} \pm 0.18$ & $8.67^{\mathrm{b}} \pm 0.11$ & $7.24^{\mathrm{b}} \pm 0.22$ \\
\hline Group 3 (mannan) & & $6.25 \pm 0.12$ & $3.68^{\mathrm{b}} \pm 0.19$ & $9.75^{\mathrm{a}} \pm 0.08$ & $8.02^{\mathrm{a}} \pm 0.13$ \\
\hline Sig. & \multirow{4}{*}{$\frac{\hat{z}}{\mathbb{d}}$} & NS & $*$ & $* *$ & $* *$ \\
\hline Group 1 (control) & & $7.33 \pm 0.16$ & $5.44^{\mathrm{a}} \pm 0.26$ & $7.51^{\mathrm{c}} \pm 0.14$ & $7.07^{\mathrm{c}} \pm 0.09$ \\
\hline Group 2 (lignin) & & $6.69 \pm 0.62$ & $4.61^{\mathrm{b}} \pm 0.03$ & $9.50^{\mathrm{b}} \pm 0.02$ & $8.43^{\mathrm{b}} \pm 0.02$ \\
\hline Group 3 (mannan) & & $6.35 \pm 0.48$ & $3.47^{\mathrm{c}} \pm 0.15$ & $10.86^{\mathrm{a}} \pm 0.14$ & $9.48^{\mathrm{a}} \pm 0.02$ \\
\hline Sig. & \multirow{5}{*}{$\begin{array}{l}0 \\
\frac{0}{0} \\
a \\
a\end{array}$} & NS & $* *$ & $* *$ & $* *$ \\
\hline Group 1 (control) & & $7.71 \pm 0.00$ & $5.12^{\mathrm{a}} \pm 0.19$ & $7.66^{\mathrm{b}} \pm 0.09$ & $7.97^{\mathrm{c}} \pm 0.13$ \\
\hline Group 2 (lignin) & & $7.07 \pm 0.80$ & $4.45^{\mathrm{b}} \pm 0.10$ & $9.74^{\mathrm{a}} \pm 0.03$ & $9.16^{\mathrm{b}} \pm 0.02$ \\
\hline Group 3 (mannan) & & $6.75 \pm 0.49$ & $3.37^{\mathrm{c}} \pm 0.13$ & $10.27^{\mathrm{a}} \pm 0.02$ & $10.37^{\mathrm{a}} \pm 0.03$ \\
\hline Sig. & & NS & $* *$ & $* *$ & $* *$ \\
\hline
\end{tabular}

Means in the same column within each classification bearing different letters are significantly different.

$\mathrm{NS}=$ Not significant, $*(\mathrm{P} \leq 0.05)$ and $* *(\mathrm{P} \leq 0.01)$.

bifidobacteria and other beneficial microorganisms and they would occupy the adhesion sites in the intestine and inhibit the adhesion of pathogenic bacteria in the intestine through competitive expulsion (Guan et al., 2011).

\section{Susceptibility of bifidobacteria and lactobacilli isolates to antimicrobial agents}

The resistance patterns of the six isolates (Ma5, $\mathrm{Mc} 22, \mathrm{Mb}_{15}, \mathrm{Lb}_{20}, \mathrm{La}_{9}$ and $\mathrm{Lc}_{25}$ ) against 15 antibiotics are shown in Table 3. Generally, there was a variation in the susceptibility of the bacterial isolates to antibiotics, as well as in the levels of strength of the tested antibiotics. Based on the average zone of inhibition for each antibiotic with all tested bacteria, Table 3 shows that ciprofloxacin (CIP) was the strongest one, reaching up to $32 \mathrm{~mm}$ followed by vancomycin (VA) reaching up to $22 \mathrm{~mm}$. On the other hand, cefotaxime (CTX) was the weakest toward the tested bacteria reaching up to $09 \mathrm{~mm}$, followed by kanamycin (K) and streptomycin (S) reaching up to $10 \mathrm{~mm}$ and erythromycin (E) reaching up to $11 \mathrm{~mm}$. Regarding, the bacterial isolates $\left(\mathrm{Ma}_{5}\right)$ was the most sensitive to the tested antibiotics reaching an average inhibition of $18 \mathrm{~mm}$, followed by $\left(\mathrm{Lc}_{25}\right)$ reaching up to 17 $\mathrm{mm}$. While, $\mathrm{La}_{9}$ was the most resistant bacteria to the tested antibiotics reaching up to $09 \mathrm{~mm}$, followed by $\left(\mathrm{Mb}_{15}\right)$ and $\left(\mathrm{Lb}_{20}\right)$ reaching up to 14 $\mathrm{mm}$. Despite the adverse effects of adding antibiotics to the broilers feed, it is stille a common practice in chicken rearing. Testing the antibiotic resistance of these isolated lactic acid bacteria in this study is of special significance, since the more resistant the bacterial strains, the more likely to persist in the colon of the chickens, and there by, impose their nowadays, its positive probiotic effect on the birds health.

\section{Antibacterial Activity of the Isolated Probiotic Bacteria}

Results in Table 4 show that antibacterial activity of the isolated bacteria from cecum of Japanes quails. All of the isolates were proved to be effective against all indicator pathogens used in this study. The antibacterial activity of $\left(\mathrm{La}_{9}\right)$ showed the highest inhibition zone against Gram 
Table 3. Susceptibility of bifidobacteria and lactobacilli isolates to antimicrobial agents using the disc diffusion method

\begin{tabular}{|c|c|c|c|c|c|c|c|c|c|c|c|c|c|c|c|c|}
\hline Tested bacteria & $\mathrm{CN}^{1}$ & $\mathbf{N}$ & $\mathbf{A X}$ & $\mathbf{S}$ & $\bar{E}$ & $\mathbf{G}$ & CTX & $\mathbf{C}$ & $\overline{V A}$ & $\mathbf{A N}$ & SXT & TE & $\mathbf{K}$ & CIP & $\overline{\mathbf{A M}}$ & $\begin{array}{c}\text { Average of } \\
\text { inhibition zone }\end{array}$ \\
\hline Isolate ( $\left.\mathrm{Lc}_{25}\right)$ & 23 & 14 & 11 & 07 & 14 & 12 & 00 & 13 & 24 & 20 & 20 & 18 & 16 & 35 & 24 & 17 \\
\hline Isolate (La) & 02 & 00 & 00 & 21 & 08 & 14 & 00 & 00 & 33 & 02 & 00 & 19 & 00 & 34 & 00 & 09 \\
\hline Isolate $\left(\mathbf{L b}_{20}\right)$ & 13 & 11 & 10 & 00 & 19 & 23 & 20 & 00 & 00 & 26 & 00 & 21 & 12 & 31 & 26 & 14 \\
\hline Isolate $\left(\mathbf{M b}_{15}\right)$ & 12 & 07 & 40 & 20 & 14 & 06 & 16 & 14 & 19 & 12 & 00 & 18 & 00 & 32 & 00 & 14 \\
\hline Isolate $\left(\mathbf{M c}_{22}\right)$ & 00 & 23 & 17 & 04 & 00 & 21 & 00 & 12 & 30 & 00 & 24 & 30 & 12 & 30 & 22 & 15 \\
\hline Isolate $\left(\mathbf{M a}_{5}\right)$ & 21 & 15 & 12 & 12 & 13 & 14 & 19 & 33 & 24 & 20 & 25 & 19 & 17 & 30 & 00 & 18 \\
\hline $\begin{array}{l}\text { Average antibiotics } \\
\text { strength tested }\end{array}$ & 12 & 12 & 15 & 10 & 11 & 15 & 09 & 12 & 22 & 13 & 12 & 20 & 10 & 32 & 12 & \\
\hline
\end{tabular}

1: CN, Gentamicin; N, Neomycin; AX, Amoxicillin; S , Streptomycin; E, Erythromycin; G, Penicillin; CTX, Cefotaxime; C, Chloramphenicol; VA, Vancomycin; AN, Aminosidin; SXT, Trimethoprim/ Sulphamethoxazole; TE, Tetracycline ;K, Kanamycin; CIP, Ciprofloxacin ; AM, Ampicillin .

Table 4. Antibacterial activity of probiotic bacteria isolated from cecum of Japanes quail against some indicator pathogens

\begin{tabular}{|c|c|c|c|c|c|c|c|}
\hline Indicator pathogen & $\begin{array}{l}\text { Isolate } \\
\left(\mathbf{L c}_{25}\right)\end{array}$ & $\begin{array}{c}\text { Isolate } \\
\left(\mathrm{La}_{9}\right)\end{array}$ & $\begin{array}{c}\text { Isolate } \\
\left(\mathbf{L b}_{20}\right)\end{array}$ & $\begin{array}{l}\text { Isolate } \\
\left(\mathbf{M b}_{15}\right)\end{array}$ & $\begin{array}{l}\text { Isolate } \\
\left(\mathbf{M c}_{22}\right)\end{array}$ & $\begin{array}{c}\text { Isolate } \\
\left(\mathrm{Ma}_{5}\right)\end{array}$ & $\begin{array}{l}\text { Average of } \\
\text { inhibition } \\
\text { zone }\end{array}$ \\
\hline Listeria monocytogenese & 1.7 & 1.5 & 1.4 & 1.6 & 1.7 & 1.7 & 1.6 \\
\hline Salmonella enteric & 1.6 & 1.7 & 1.4 & 1.4 & 1.3 & 1.4 & 1.5 \\
\hline E.coli O157:H7 & 1.3 & 1.0 & 1.2 & 0.6 & 0.7 & 0.8 & 0.9 \\
\hline Enterobacter cloacae subsp. dissolvens. & 1.7 & 1.6 & 1.6 & 1.6 & 1.3 & 1.3 & 1.5 \\
\hline Enterobacter aerogenes & 1.7 & 1.7 & 1.6 & 1.3 & 1.4 & 1.5 & 1.5 \\
\hline Maicrococcus caseolyticus & 1.5 & 2.2 & 1.5 & 2.0 & 1.5 & 1.9 & 1.8 \\
\hline Aeromounas hedrophili & 1.7 & 1.3 & 1.3 & 1.6 & 1.2 & 1.3 & 1.4 \\
\hline Staphylococcus aureus & 1.8 & 1.5 & 1.6 & 1.0 & 1.3 & 1.1 & 1.4 \\
\hline Staphylococcus $\boldsymbol{H}$ & 1.4 & 1.5 & 1.3 & 1.4 & 1.4 & 1.6 & 1.4 \\
\hline Average of bacteria isolates strength tested & 1.6 & 1.5 & 1.4 & 1.3 & 1.3 & 1.4 & \\
\hline
\end{tabular}


positive Macrococcus caseolyticus (22 mm), while showed the lowest inhibition zone against the gram negative bacteria E.coli $(10 \mathrm{~mm})$. Average inhibition zone aginst Listeria monocytogenese and Macrococcus caseolyticus reached to $(1.6 \mathrm{~mm})$ and $(1.8 \mathrm{~mm})$, respectively, whereas, at Enterobacter aerogenes reached to $(1.5 \mathrm{~mm})$. The antibacterial activity of the crude supernatant fluids obtained from LAB culutures was generally greater against the Gram positive than the Gram negative tested bacteria. Similar antibacterial results, were obtained by Zhu et al. (2012), who obtained that this effect could be explained on the bases of the difference in the chemical composition of the bacterial cell well. In Gram positive bacteria, as much as $90 \%$ of the cell wall consists of pepedoglycan, beside teichoic acids while in Gram negative only about $10 \%$ of the total cell wall consists of peptidoglycan. Instead, most of the gram negative cell wall is composed of the outer membrane containing polysaccharides linked to lipids to form a complex called lipopolysaccharide (Madigan et al., 2012).

Mannan oligosaccharides are able to bind with certain intestinal microbiota due to the mannan component attachment of microbiota to the intestinal cells (Spring et al., 2000). Also, Mannan oligosaccharide reduces pathogen colonization by acting as an analogous receptor to type I fimbriae and by decreasing the number of binding sites in the intestin (Patterson and Burkholder, 2003).

\section{Identification of Bacterial Isolates}

The results for the identification of the aforementioned isolates based on the biochemical tests shown by Martin-Carnahan and Joseph (2005) are presented in Table 5. The isolates were identified as Bifidobacterium longum subspp.. infantis $\left(\mathrm{La}_{9}\right)$, Bifidobacterium animalis subspp. lactis $\left(\mathrm{Mb}_{15}\right)$ and Lactobacillus acidophilus $\left(\mathrm{Lb}_{20}\right)$. The identification was primarily based on the biochemical tests then the sequencing of the 16S rRNA gene was employed only with three isolates to confirm the identification process and these strains were identified as which as Bifidobacterium longum subspp. infantis, Bifidobacterium animalis subspp.. Lactis and Lactobacillus acidophilus. These strains were isolated from cecum of Japanes quails with mannan and lignin addition at 6 weeks of age.

\section{S rRNA Identification of the bacterial Isolates}

Three of these isolates were selected as they were the most resistant for antibiotics and had higher ability for antibacterial activity against pathogenic bacteria. Generally, sequencing of the 16S rRNA gene has proven to be valuable in the identification of bifidobacterium spp. and Lactobacillus spp. Analysis of 16S rRNA gene was considered to be a rapid and powerful method for identifying isolates of bifidobacterium spp. and Lactobacillus spp. to the species level (Borrell et al., 1997). The amplified 16S rDNA gene products of representative isolates $(n=6)$ from each identified group in $16 \mathrm{~S}$ rDNA were sequenced using primer F:-AGA GTT TGA TCC TGG CTC AG, R:-GGT TAC CTT GTT ACG ACT $\mathrm{T}$., from a commercial sequencing facility (Sigma Labs). The sequences were aligned independently and phylogenetically analysed using GATC Company by use ABI 3730xl DNA sequencer [Gene JET ${ }^{\mathrm{TM}}$ ] (Saitou and Nei, 1987). The sequencing of the $16 \mathrm{~S}$ rDNA gene showed that the closest strain relatedness of Bifidobacterium longum subsp. infantis ( $\left.\mathrm{La}_{9}\right)$, Bifidobacterium animalis subsp. lactis $\left(\mathrm{Mb}_{15}\right)$ and Lactobacillus acidophilus $\left(\mathrm{Lb}_{20}\right)$ as showen in Table 6 .

\section{Conclusion}

Supplementation of the diet with Mannanoligosaccharide (MOS at $0.2 \%$ ) or Lignin ( $\mathrm{L}$ at $1.25 \%$ ) can enhance quail immunology by selectively stimulating the beneficial intestinal microflora. Specially adding mannan which can increase count of beneficial bacteria such as bifidobacterium and lactobacilli in the ceca. MOS also resulted in a major reduction in E.coli counts. In this investigation, selected characteristics of the physiological functionalities of Lactobacillus spp. and Bifidobacterium spp. were recorded in vitro tests of the above bacterial strains did not support their classification among probiotics, results of selected in vitro microbiological tests nevertheless suggested that the tested microorganisms show some abilites ascribed to probiotic microorganisms. The characteristics of the strains mentioned are assumed to be futher studied. 
Table 5. Biochemical properties of the six isolated bacteria from cecum of Japanes quails at different stages of age

\begin{tabular}{lcccccc}
\hline Characteristic & \multicolumn{6}{c}{ Bacterial isolates } \\
\cline { 2 - 7 } \multicolumn{1}{c}{$\mathbf{M a}_{\mathbf{5}}$} & $\mathbf{L a}_{\mathbf{9}}$ & $\mathbf{M b}_{\mathbf{1 5}}$ & $\mathbf{L b}_{\mathbf{2 0}}$ & $\mathbf{M c}_{22}$ & $\mathbf{L c}_{\mathbf{2 5}}$ \\
\hline Indole production & - & - & - & - & - & - \\
Methyl red & + & + & + & + & + & + \\
Voges proskauer & - & - & - & - & - & - \\
Citrate utilization & + & + & + & + & - & - \\
H2S production & + & + & + & + & + & - \\
Urea hydrolysis & - & - & - & - & - & - \\
Motility & - & - & - & - & - & + \\
Acid mannitol & + & + & + & + & + & + \\
Acid glucose & + & + & + & + & + & + \\
Gas glucose & + & + & + & + & + & - \\
Oxidases & + & + & + & + & + & + \\
Lactose & + & + & + & + & + & + \\
Sucrose & + & + & + & + & + & + \\
Inositol & + & + & + & + & + & - \\
Raffinose & - & - & - & - & - & - \\
Mannose & + & + & + & + & + & + \\
Sorbitol & + & + & + & + & + & + \\
Trehalose & + & + & + & - & - & + \\
Ribose & - & - & - & - & - & - \\
Rhuminose & - & - & - & - & - & - \\
Cellobiose & - & - & - & - & - & - \\
Catalase & + & + & + & + & + & + \\
\hline
\end{tabular}

$\mathrm{Ma}_{5}$ : isolate from mannan group at 3 weeks of age. $\quad \mathrm{La}_{9}$ : isolate from lignin group at 3 weeks of age. $\mathrm{Mb}_{15}$ : isolate from mannan group at 6 weeks of age. $\mathrm{Lb}_{20}$ : isolate from lignin group at 6 weeks of age. $\mathrm{Mc}_{22}$ : isolate from mannan group at 9 weeks of age. $\mathrm{Lc}_{25}$ : isolate from lignin group at 9 weeks of age.

Table 6. Identification of three Bifidobacterium and Lactobacillus species

\begin{tabular}{clll}
\hline Isolate & Identification by biochemical and 16S rRNA & \multicolumn{2}{c}{ International bacterial strains } \\
\hline La $_{9}$ & Bifidobacterium longum subsp. infantis & Bifidobacterium longum subsp. Infantis \\
& & strain ATCC 15697 16S ribosomal RNA \\
& & gene, partial sequence. \\
$\mathbf{M b}_{\mathbf{1 5}}$ & Bifidobacterium animalis subsp. lactis & Bifidobacterium animalis subsp. lactis strain \\
& & YIT 4121 16S ribosomal RNA gene, partial \\
& & sequence \\
$\mathbf{L b}_{\mathbf{2 0}}$ & Lactobacillus acidophilus NCFM strain & Lactobacillus acidophilus NCFM strain \\
& NCFM & NCFM, 16S ribosomal RNA gene, complete \\
& & sequence \\
\hline
\end{tabular}




\section{REFERENCES}

Apajalahti, J. and M. Bedford (2001). Impact of dietary and environmental factors on microbial communities of the avian GI tract. Worlds Poult. Sci. Cong., Montreal. $.60: 1575-1592$.

Baurhoo, B., A. Letellier, X. Zhao and C.A. Ruiz-Feria (2007b). Cecal populations of lactobacilli and bifidobacteria and Escherichia coli populations after in vivo Escherichia coli challenge in birds fed diets with purified lignin or mannan oligosaccharides. Poult. Sci., 86 : 2509-2516.

Baurhoo, B., L. Phillip and C.A. Ruiz-Feria (2007a). Effects of purified lignin and mannan oligosaccharides on intestinal integrity and microbial populations in the ceca and litter of broiler chickens. Poult. Sci., 86: 1070-1078.

Borrell, N., S.G. Acinas, M.J. Figueras and A.J. Martins-Murcia (1997). Identification of probiotic isolates by restriction fragment length polymorphism of PCRamplified 16S rRNA genes. J. Clin. Microbiol., 35: 16711674.

Choct, M., R.J. Hughes, J. Wang, M.R. Bedford, A.J. Morgan and G. Annison (1996). Increased small intestinal fermentation is partly responsible for the anti-nutritive activity of non-starch polysaccharides in chickens. Br. Poult. Sci., 37:609-621.

Costa, A.B., K. Kanai and K. Yoshikoshi (1998). Serological characterization of a typical strains of Edwardsiella tarda isolated from SeaBream . Fish Pathol., 33 : 265-274.

Gibson, G.R. and M.B. Roberfroid (1995). Dietary modulation of the human colonic microbiotica: Introducing the concept of prebiotics. J. Nut., $125: 1404-1412$.

Gouveia, E.M.F., I.S. Silva, V.J. Van Onselem, R.A.C. Correa and C.J. Silva (2006). Use of mannan oligosaccharides as an adjuvant treatment for gastrointestinal diseases and thier effects on $E$. coli inactivated in dogs. Acta. Cir. Bras., 21.
Greko, C. (2001). Safety aspects on non-use of antimicrobials as growth promoters. In: Piva, A. et al. Eds. Gut Environment of Pigs. Nottingham Univ. Press, Nottingham, UK; 219-230.

Guan, Y. (2011). Nucleosome-coupled expression differences in closely-related species. BMC Gen., 12 (1): 466.

Herreros, M.A., H. Sandoval, L. Gonzalez, J.M. Castro, J.M. Fresno and M.E. Tornadijo (2005). Antimicrobial activity and antibiotic resistance of lactic acid bacteria isolated from food. Food Microbiol., 22: 455-459.

Klasing, K.C., B.K. Johnstone and B.N. Benson (1999). Recent developments in Poultry Nutrition 2. Eds P.C. Garnsworthy and J. Wiseman. Nottingham Univ. Press, Nottingham.

Langlands, S.J., M.J. Hopkins, N. Coleman and J.H. Cummings (2004). Prebiotic carbohydrates modify the mucosa associated microflora of the human large bowel. Gut., 53:1610-1616.

Madigan, M.T., J.M. Martinko, D.A. Stahl and D.P. Klark (2012). Brock Biology of Microorganisms $13^{\text {th }}$ Ed., Benjamin Cumminges, Boston, New York.

Maniatis, T., E.F. Fritsch and J. Sambrook (1989). Molecular Cloning: A Laboratory Manual. $2^{\text {nd }}$ Ed. Cold Spring Harbor, NY, Cold Spring Harbor Laboratory Press.

Martin-Carnahan, A. and S.W. Joseph (2005). Bergey's Manual of Systematic Bacteriology $2^{\text {nd }}$ Ed., Volume Two, (The proteobacteria) Part B, The Gamma Proteobacteria.

Martinez-Murcia, A.J., S. Benlloch and M.D. Collins (1992). Phylogenetic inter relationships of members of the genera Aeromonas and Plesiomonas as determined by $16 \mathrm{~S}$ ribosomal DNA sequencing: lack of congruence with NRC: Nutrient Requirements of Poultry. $9^{\text {th }}$ Rev. Nat. Res. Council, Nat. Acad. Press. Washington, DC, USA, 1994.

Middelbos, I.S., N.D. Fastinger and G.C. Fahey (2007). Evaulation of fermentable oligosaccharides in diets fed to dogs in comparison to fiber standards. J. Anim. Sci., $85: 3033-3044$. 
NCCLS (2004). National Committee for Clinical Laboratory Standard. Performance Standards for Antimicrobial Disk Susceptibility testing. Fourteenth Inform. Supplement.

Nelson, J.L., J.W. Alexander, L. Gianotti, C.L. Chalk and T. Pyles (1994). Influence of dietary fiber on microbial growth in vitro and bacterial translocation after burn injury in mice. Nut., 10:32-36.

NRC, (1994): Nutrient Requirements of Poultry. $9^{\text {th }}$ Rev. National Research Council, National Academy Press. Washington, DC, USA.

Patterson, J.A. and K.M. Burkholder (2003). Application of prebiotics and probiotics in poultry production. Poult. Sci., 82:627-631.

Phillip, L.E., E.S. Idziak and S. Kubow (2000). The potential use of lignin in animal nutrition, and in modifying microbial ecology of the gut. In East. Nut. Conf. Anim. Nut. Assoc. Canada, Montreal, Quebec, Canada, 1-9.

Rehman, H., W. Vahjen, A. Kohl-Parisini, A. Ijaz and J. Zentek (2009). Influence of fermentable carbohydrates on the intestinal bacteria and enteropathogens in broilers. World's Poult. Sci. J., 65: 75-89.

Roe, M.T. and S.D. Pillai (2003). Monitoring and identifying antibiotic resistance in bacteria. Poult. Sci., 82: 622-626.

Saitou, N. and M. Nei, (1987): The neighborjoining method: A new method for reconstructing phylogenetic trees. Mol. Biol. Evol., 4: 406-425.

Samelis, J., F. Maurogenakis and J. Metaxopoulos (1994). Characterization of lactic acid bacteria isolated from naturally fermented Greek dry Salami. Int. J. Food. Microbiol., 23: 179-196.

Smits, H.M., A. Veldman, M.W.A. Verstegen and A.C. Beynen (1997). The effects of dietary mannan oligosaccharides on cecal parameters in broiler. J. Nut., 127: 483-487.

Snedecor, G.W. and W.G. Cochran (1982). Statistical method, $7^{\text {th }}$ ed., Iowa State Univ., Press Ames., Iowa, USA., 325-330.
Spring, P., C. Wenk, K.A. Dawson and K.E. Newman (2000). The effects of dietary mannan oligosaccharides on cecal parameters and the concentrations of enteric bacteria in the ceca of salmonella-challenged broiler chicks. Poult. Sci., 79 : 205-211.

Steenfeldt, S., K.E.B. Knudsen, C.F. Borsting and B.O. Eggum (1995). The effects of dietary mannan oligosaccharides and lignin on cecal parameters Anim. Feed Sci. and Technol., 54: 249-265.

Swanson, K.M.J., R.L. Petran and J.H. Hanlin (2001). Culture methods for enumeration of microorganisms. In: Downes, F.P. and Ito, K. Eds. Compendium of methods for the microbiological examination of foods, $4^{\text {th }} \mathrm{Ed}$. Ame. Public Health Assoc. (APHA), Washington, USA, 53-62.

Swanson, K.S. and G.C. Fahey (2006). Prebiotic impacts on companion animals. In: Gibson GR, Rastall RA (eds) Prebiotics: Develop. and Applic., New York, Wiley, 213-236.

Van Leeuwen, P., J.M.V.M. Mouwen, J.D. Vanderklis and M.W.A. Erstegen (2004). Effects of purified lignin and mannan oligosaccharides on intestinal integrity and microbial populations in the ceca of broiler chickens Bri. Poult. Sci., 45: 41-48.

Xu, Z.R., C.H., Hu, M.S. Xia, X.A. Zhan and M.Q. Wang (2003). Effects of dietary fructooligosaccharide on digestive enzyme activities, intestinal microflora and morphology of male broilers. Poult. Sci., 82: 1030-1036.

Yang, Y., P.A. Iji, A. Kocher, E. Thomson, L.L. Mikkelsen and M. Choct (2008). Effects of mannanoligosaccharide in broiler chicken diets on growth performance, energy, energy utilization, nutrient digestibility and intestinal microflora. Br. Poult. Sci., 49:186-194.

Zdunczyk, Z., J. Juskiewicz, J. Jankowski, E. Bierdrzycka and A. Koncicki (2005). Metabolic response of the gastrointestinal tract of turkeys to diets with different levels of mannan-oligosaccharide. Poult. Sci., 84 : 903-909. 
Zhu, H., H. Liu, J. Yan, R. Wang and L. Liu (2012). Effect of yeast polysaccharide on some hematologic parameter and gut morphology in channel catfish (Ictalurus punctatus). Fish Physiol. Biochem., 38: 1441-1447.

\section{تأثير التظذية بالمنان علديد التسكر واللجنين على مجموعات وخصائص البكتيريا المساعدة الحيوية المعزولة من السمان الياباني}

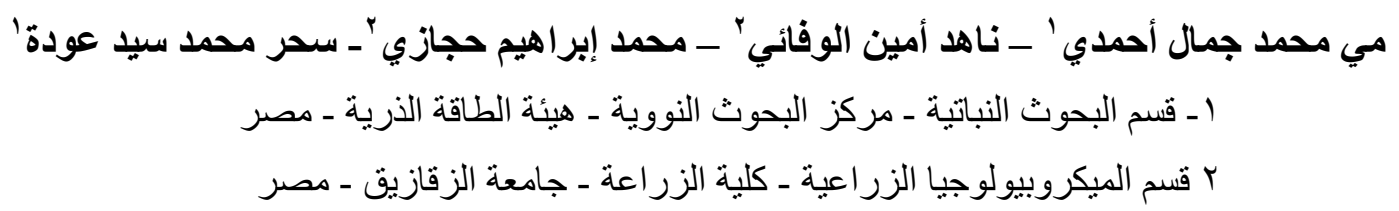

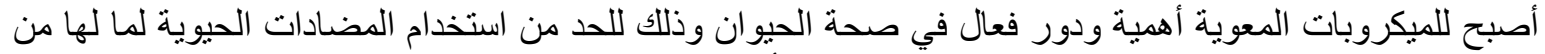

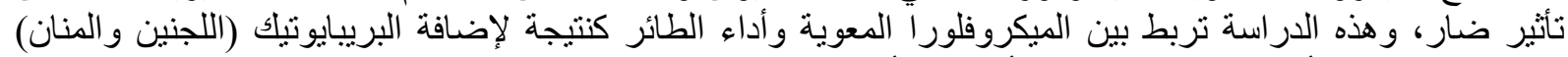

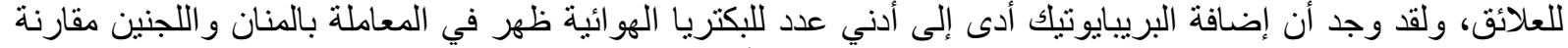

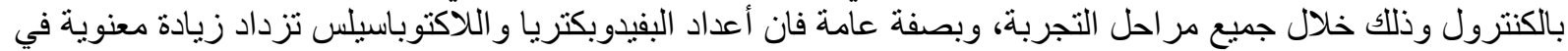

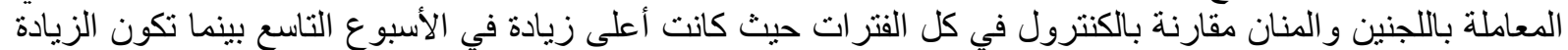

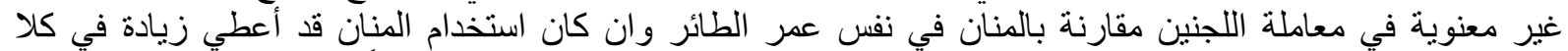

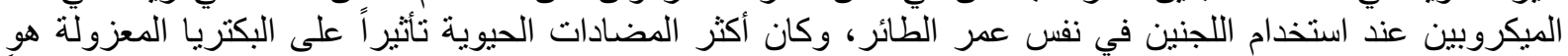

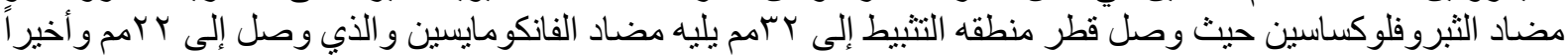

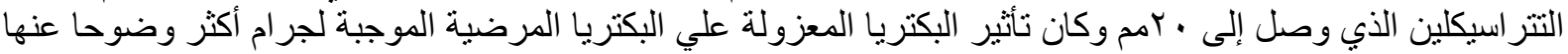

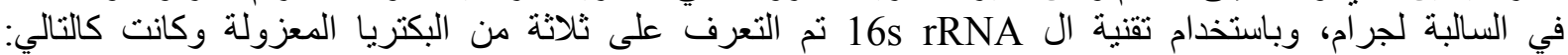
Bifidobacterium longum subsp. infantis, Bifidobacterium animalis subsp. lactis and Lactobacillus acidophilus

أستاذ الميكروبيولوجيا الزر اعية ـ كلية الزر اعة بمشتهر - جامعة بنها.

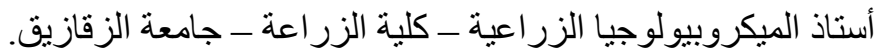

